\title{
Low prevalence of bovine tuberculosis in Somali pastoral livestock, southeast Ethiopia
}

\author{
Balako Gumi • Esther Schelling • Rebuma Firdessa • \\ Girume Erenso • Demelash Biffa • Abraham Aseffa • \\ Rea Tschopp • Lawrence Yamuah • Douglas Young • \\ Jakob Zinsstag
}

\begin{abstract}
Accepted: 17 January 2012 /Published online: 29 January 2012
\end{abstract}
(C) Springer Science+Business Media B.V. 2012
$10.0 \%$ (95\% CI, 7.0-14.0\%), and 1.9 (95\% CI, 0.9-4.0\%), respectively, whereby camels had an odds ratio of $16.5(95 \%$ CI, 5.0-55.0) when compared to cattle. There was no significant difference between livestock species in BTB positivity. In the present study, the prevalence of bovine tuberculosis was low in Somali pastoral livestock in general and in camels and goats in particular. The high proportion of camel reactors to avian PPD needs further investigation of its impact on camel production.

Keywords CIDT, bovine tuberculosis, camel, cattle, goats . Pastoralist $\cdot$ Somali region $\cdot$ Ethiopia

\section{Introduction}

Bovine tuberculosis (BTB) is a chronic bacterial disease of animals and humans and is a major infectious disease among cattle, other domesticated animals, and certain wildlife populations in a large number of countries (Cosivi et al. 1998; Schiller et al. 2010). Although cattle are considered to be the main hosts of Mycobacterium bovis, isolations have been made from many other livestock and wildlife species, and transmission to humans constitutes a public health problem (Ayele et al. 2004; OIE 2009). Aerosol exposure to $M$. bovis is considered to be the most frequent route of infection of cattle, but infection by ingestion of a contaminated material also occurs (Biet et al. 2005). The standard method for BTB detection in live animal is the comparative intradermal tuberculin test (CIDT) based on delayed hypersensitivity reactions. The CIDT test includes bovine and avian tuberculin and is used mainly to differentiate between animals infected with $M$. bovis and those sensitized to tuberculin due to exposure to other mycobacteria or related genera (OIE 2009). 
The occurrence of BTB became rare in humans and cattle in industrialized countries (Cosivi et al. 1998; Ayele et al. 2004). However, it remains an important disease in many countries of the world where BTB is endemic, causing significant economic losses (Zinsstag et al. 2006). BTB in animals has been reported from 33 of 43 African countries (Ayele et al. 2004). Human bovine tuberculosis cases have been described in some Sahelian countries like Ghana, Niger, Uganda, and Tanzania (Idigbe et al. 1986; Addo et al. 2007; Oloya et al. 2008) and in immigrants from Chad (Godreuil et al. 2010). The representative proportion of BTB in human tuberculosis is estimated at less than 5.0\% worldwide (Cosivi et al. 1998; Michel et al. 2010). In Ethiopia, BTB is endemic in cattle. Prevalence varies from $3.5 \%$ to $50.0 \%$ depending on the geographical areas, the breeds, and the husbandry practices (Shitaye et al. 2007; Berg et al. 2009; Demelash et al. 2009; Regassa et al. 2010). Prevalence in traditionally kept zebu cattle varies between $0.9 \%$ and $4.0 \%$ based on different cutoff values used for interpretation (Tschopp et al. 2010). Based on gross pathology, prevalence of $5.0-10.0 \%$ was reported in camels slaughtered at Dire Dawa abattoir in eastern Ethiopia and in Addis Ababa abattoir (Mamo et al. 2009, 2011). Hiko and Agga (2011) reported $4.2 \%$ prevalence of bovine TB in goats slaughtered at Mojo export abattoir in central Ethiopia based on gross lesions.

To date, there are no reports on the CIDT status in Somali pastoral livestock in southeast Ethiopia, and information on BTB among the pastoral livestock is generally limited. Therefore, the objectives of the present study were to assess the prevalence of tuberculin reactors in the Somali pastoral livestock in southeast Ethiopia and to evaluate the determinants of tuberculin-reacting animals.

\section{Materials and methods}

\section{Study area}

A cross-sectional cluster sampling study was conducted from January to August 2009 in Filtu Woreda of Liben zone in the Somali regional state in southeast Ethiopia (Fig. 1). Pastoralists in the study area kept their animals extensively. Climatic condition of the area was characterized by arid weather with bimodal rainfall pattern. Considering Filtu town (zonal capital) as the reference center, four pastoral associations (PAs) were selected for this study that were located geographically on the three directions, except Bakaka PA, and in a distance of 25-40 km from Filtu, namely Hayadimtu in the northwest, Bifatu PA in the southeast, Melkalibe PA in the northeast, and Bakaka PA was conveniently included from the nearby Filtu town due to security reason.

\section{Sample size}

The sample size for tuberculin testing was calculated using a cluster sampling formula provided by Bennett et al. (1991). Herds were considered as clusters. We assumed an intraclass correlation coefficient (rho) of 0.2 , an expected prevalence of $3 \%$, and a standard error of $1.5 \%$. The total sample size calculated was 1,440 animals in 96 herds for all livestock species. The calculated sample size per livestock species was 480 in 32 herds.

In all four PAs, a list of households interested to participate in the study was established during general PA meetings and used as a sampling frame. Eight households were randomly selected from the list for each PA (using random number technique).

For each livestock species, 15 animals with age of greater or equal to 1 year were selected per herd, and unique identification numbers were given for each tested animal together with sex, age, and body condition score (BCS). The animals were categorized into the following age groups: young (1-2.5 years), adult (2.6-6 years), and old ( $>6$ years). BCS was assessed using a modified guideline described by Msangi et al. (1999), and cattle were classified as emaciated (score 1), thin (score 2), normal (score 3), musculous (score 4), and fat (score 5). For camels, BCS was based on hump scoring (amount of fat in the hump) which ranged from 1 to $5 \mathrm{http}: / /$ www.camelsaust.com. $\mathrm{au} /$ livebodycond.htm. Goats were categorized as emaciated (1), normal (2), and well conditioned (3).

\section{Tuberculin skin testing}

The CIDT was performed using both bovine and avian purified protein derivative (PPD) obtained from the Veterinary Laboratories Agency, Addlestone, Surrey, UK. Two injection sites were in the middle third of the side of the neck, one above the other, separated at least $12 \mathrm{~cm}$ for cattle and camels, while injection sites were on both sides of the neck in goats. The hair was shaved around the sites to a radius of about $2 \mathrm{~cm}$. Skin fold at both sites was measured with a caliper and the measurements recorded. An aliquot of tuberculin containing 2,500 IU/0.1 $\mathrm{ml}$ bovine PPD was injected into the skin intradermally at the lower injection site, and similarly, tuberculin containing 2,500 IU/0.1 ml avian PPD was injected at the upper site for cattle and camels, and for goats, avian PPD on the right and bovine PPD on the left side of the neck. After $72 \mathrm{~h}$, the thickness of the same skin fold at both sites was measured and recorded.

Bovine and avian positive reactors were obtained using the formula: $\left[\left(\mathrm{Bov}_{72}-\mathrm{Bov}_{0}\right)-\left(\mathrm{AV}_{72}-\mathrm{Av}_{0}\right)\right]$ and $\left[\mathrm{AV}_{72}-\mathrm{Av}_{0}\right)-$ $\left.\left(\mathrm{Bov}_{72}-\mathrm{Bov}_{0}\right)\right]$, respectively. $\mathrm{Bov}_{0}$ and $\mathrm{Av}_{0}$ indicated skin thickness before injecting bovine and avian tuberculin, and $\mathrm{Aov}_{72}$ and $\mathrm{Bov}_{72}$ were the corresponding skin fold thickness 


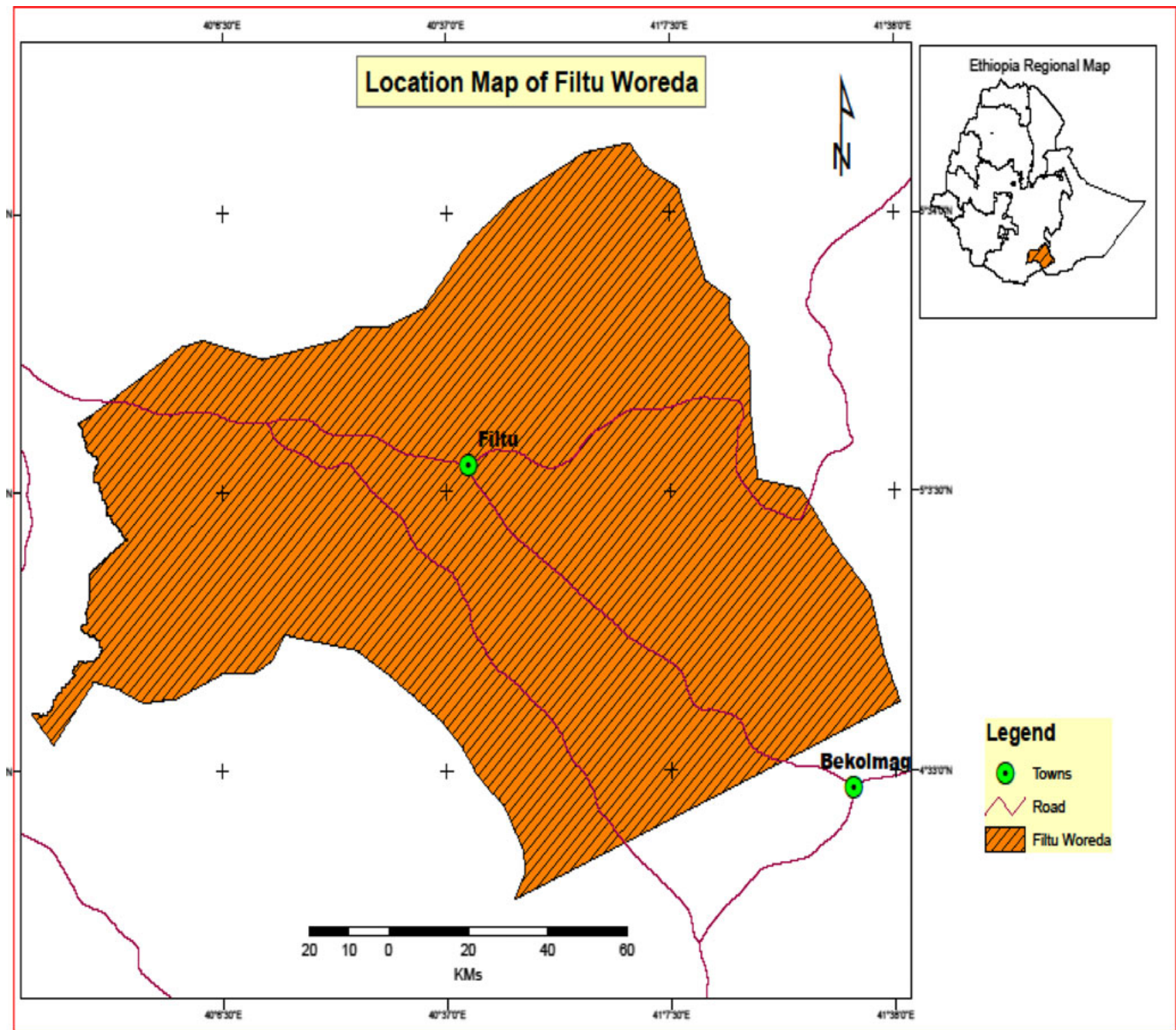

Fig. 1 Location map of the study area

$72 \mathrm{~h}$ post-injection. The tuberculin test results were interpreted based on OIE-recommended cutoff of $>4 \mathrm{~mm}$. Increase in skin fold thickness of $>4 \mathrm{~mm}$ was regarded as positive reactor, 1 to $4 \mathrm{~mm}$ doubtful reactor, and negative if the increase in skin thickness at the bovine site of injection was less than the increase in the skin fold thickness at the avian site of injection. Increase in skin fold thickness of $>1 \mathrm{~mm}$ with visible reaction at avian site than at the bovine site was considered as positive for Mycobacterium avium spp.

\section{Questionnaire survey}

To assess possible risk factors associated with husbandry practices and production system for tuberculin positivity and exposure to BTB infection, all herd owners of tuberculintested animals were interviewed using pre-tested structured questionnaires.

Data entry and analysis

The data were double entered in Microsoft Access 2002 (Microsoft Corp. Redmond, USA) and validated with Epi Info version 3.3.2 before being imported to Stata 10/SE (Stata Corp., College Station, TX) for analysis. The outcome of all statistical analyses was individual animal species and herd-level binary outcomes. A herd was considered positive if it had at least one tuberculin reactor. Prevalence was calculated using xtgee model for each species. 


\section{Result}

Individual animal prevalence

A total of 1,418 animals from 94 randomly selected herds with 34 goat herds, 32 camel herds, and 28 cattle herds in Hayadimtu, Bifatu, Melkalibe, and Bakaka PAs were tuberculin tested. A total of 421 cattle, 479 camels, and 518 goats were tested. The individual animal prevalence was $2.0 \%$ [95\% confidence interval (CI) $0.5-8.4], 0.4 \%$ (95\% CI, $0.1-3 \%)$, and $0.2 \%(95 \% \mathrm{CI}, 0.03-1.3 \%)$ in cattle, camels, and goats, respectively (Table 1). There was no significant difference in tuberculin positivity between animal species.

Prevalence of avian PPD reactors in cattle, camels, and goats was $0.7 \%$ (95\% CI, 0.2-2.0\%), 10.0\% (95\% CI, $7.0-$ $14.0 \%)$, and $1.9(95 \% \mathrm{CI}, 0.3-4.0 \%)$, respectively. Camels had an odds ratio (OR) of 16.5 (95\% CI, 5.0-55.0) for avian PPD positivity when compared to cattle.

\section{Herd prevalence}

Prevalence of bovine PPD reactor herds in cattle, camels, and goats was $14.3 \%(95 \% \mathrm{CI}, 0.5-28.0 \%), 3.1 \%(95 \% \mathrm{CI}$, $-3.2-9.5 \%)$, and $2.9 \%$ (95\% CI, -3.0-9.0\%), respectively, with no significant differences (Fisher's exact test) among herds of different animal species in BTB positivity (Table 2). No significant association was found between reactor herds and various numbers of hypothesized risk factors.

\section{Discussion}

The low BTB prevalence $(<1.0 \%$ for camels and goats, and $2.0 \%$ for cattle) in our study was comparable with the reports from different regions of Tanzania: $0.9 \%$ (Cleaveland et al. 2007), 0.7\% (Weinhäupl et al. 2000), 1.3\% (Shirima et al. 2003), 0.2\% (Jiwa et al. 1997), Uganda 1.3\% (Inangolet et al. 2008), 1.4\% (Oloya et al. 2006), and Ethiopia $0.9 \%$ (Tschopp et al. 2010). However, various other results were reported from Pakistan (2.4\% in goats; Javed et al. 2010), Eritrea (14.5\% in cattle; Omer et al. 2001), Zambia (6.8\% in cattle; Munyeme et al. 2009), Tanzania (13.2\% in
Table 2 Herd prevalence among three livestock species in the study area

\begin{tabular}{lclc}
\hline $\begin{array}{l}\text { Animal } \\
\text { species }\end{array}$ & $\begin{array}{l}\text { Number of } \\
\text { herd tested }\end{array}$ & $\begin{array}{l}\text { Positive } \\
\text { herd (\%) }\end{array}$ & $95 \%$ CI \\
\hline Cattle & 28 & $4(14.3)$ & $0.5-28$ \\
Camel & 32 & $1(3.1)$ & $-3.2-9.5$ \\
Goats & 34 & $1(2.9)$ & $-3.0-9.0$ \\
\hline
\end{tabular}

cattle; Kazwala et al. 2001), and from cattle in different regions of Ethiopia: 46.8\% (Ameni et al. 2003), 19\% (Shitaye et al. 2006), 11\% (Ameni and Erkihun 2007), 9.7\% (Fetene and Kebede 2009), and $11.6 \%$ (Regassa et al. 2010). The inter-study variations may be due to differences in management practices, production system, types of animal species and breeds, or differences in ecological zones. A higher BTB prevalence rate of $5.5 \%$ was reported in neighboring Oromia pastoralist in cattle (Gumi et al. 2011). The pastoralist and agro-pastoralist production systems in neighboring Oromia pastoralist may explain this difference between the communities.

Avian PPD prevalence of $10.0 \%$ detected in camel in the present study is in line with a report of $10.0 \%$ (Shirima et al. 2003) and 11.0\% (Fetene and Kebede 2009) in cattle from Zambia and Ethiopia, respectively. However, in contrast to our study, in these studies cattle and goats also showed relatively high proportions of avian PPD reactors. The observed differences in prevalence of avian PPD among three livestock species that are kept and pastured together might be due to different susceptibility to non-BTB mycobacteria.

In our observations, the herd prevalence of BTB is much lower compared to other authors (Kazwala et al. 2001; Omer et al. 2001; Ameni et al. 2003; Oloya et al. 2006, 2007; Shitaye et al. 2006; Munyeme et al. 2008; Fetene and Kebede 2009; Regassa et al. 2010) in the cattle herds in Ethiopia and the different countries of the region. This could be due to difference in agro-ecological zones and production systems.

Risk factors such as herd size, herd keeping with other livestock species, contact with other herds, and annual migration dynamics, recent introduction of new animals to herd, and other risk factors could not be associated with

Table 1 Prevalence of bovine and avian PPD reactor in cattle, camels, and goats in the study area

\begin{tabular}{|c|c|c|c|c|c|c|}
\hline \multirow{2}{*}{$\begin{array}{l}\text { Animal } \\
\text { species }\end{array}$} & \multicolumn{2}{|l|}{ Bovine PPD } & \multicolumn{2}{|l|}{ Avian PPD } & \multicolumn{2}{|l|}{ Univariate analysis } \\
\hline & $\begin{array}{l}\text { Number test } \\
\text { negative }\end{array}$ & $\begin{array}{l}\text { Number test positive } \\
(\%), 95 \% \text { CI }\end{array}$ & $\begin{array}{l}\text { Number test } \\
\text { negative }\end{array}$ & $\begin{array}{l}\text { Number test positive } \\
(\%), 95 \% \mathrm{CI}\end{array}$ & $\begin{array}{l}\text { Bovine PPD OR } \\
(95 \% \mathrm{CI})\end{array}$ & $\begin{array}{l}\text { Avian PPD OR } \\
(95 \% \mathrm{CI})\end{array}$ \\
\hline Cattle & 411 & $10(2.0), 0.5 .0-8.4$ & 317 & $3(0.7), 0.2-2.0$ & 1 & 1 \\
\hline Camel & 477 & $2(0.4), 0.1-3.0$ & 429 & $50(10.0), 7-14.0$ & $0.2(0.01-4)$ & $16.5(5.0-55.0)$ \\
\hline Goats & 517 & $1(0.2), 0.03-1.3$ & 508 & $10(1.9), 0.9-4.0$ & $0.2(0.01-3.0)$ & $2.7(0.7-10.0)$ \\
\hline
\end{tabular}


herd positivity to BTB. The high degree of similarities in a livestock management in pastoralist communities in study area may mask the effect of risk factors related to husbandry practices.

In the present study, prevalence of BTB was low in Somali pastoral livestock. The high proportion of camel reactors to avian PPD deserves further investigation of the responsible mycobacterial agent and a possible impact on livestock, in this case, camel productivity.

Acknowledgment We would like to thank the Wellcome Trust Fund Program on Bovine Tuberculosis in Ethiopia and the Armauer Hansen Research Institute for their financial support to the research work. The National Centre of Competence in Research North-South is acknowledged for its co-founding to field work supervision.

\section{References}

Addo, K., Owusu-Darko, K., Yeboah-Manu, D., Caulley, P., Minamikawa, M., Bonsu, F., Leinhardt, C., Akpedonu, P., Ofori-Adjei, D., 2007. Mycobacterial Species Causing Pulmonary Tuberculosis at the Korle Bu Teaching Hospital, Accra, Ghana. Ghana Medical Journal 41(2), $52-57$.

Ameni, G., Bonnet, P., Tibbo, M., 2003. A Cross-sectional Study of Bovine Tuberculosis in Selected Dairy Farms in Ethiopia. The International Journal of Applied Research in Veterinary Medicine 1(4), 85-97.

Ameni, G., Erkihun, A., 2007. Bovine tuberculosis on small-scale dairy farms in Adama Town, central Ethiopia, and farmer awareness of the disease. Revue Scientifique Et Technique (International Office of Epizootics) 26(3), 711-9.

Ayele, W.Y., Neill, S.D., Zinsstag, J., Weiss, M.G., Pavlik, I., 2004. Bovine tuberculosis: an old disease but a new threat to Africa. The International Journal of Tuberculosis and Lung Disease: The Official Journal of the International Union Against Tuberculosis and Lung Disease 8(8), 924-37.

Bennett, S., Woods, T., Liyanage, W.M., Smith, D.L., 1991. A simplified general method for cluster-sample surveys of health in developing countries. World Health Statistics Quarterly. Rapport Trimestriel De Statistiques Sanitaires Mondiales 44(3), 98-106.

Berg, S., Firdessa, R., Habtamu, M., Gadisa, E., Mengistu, A., Yamuah, L., Ameni, G., Vordermeier, M., Robertson, B.D., Smith, N.H., Engers, H., Young, D., Hewinson, R.G., Aseffa, A., Gordon, S.V., 2009. The Burden of Mycobacterial Disease in Ethiopian Cattle: Implications for Public Health. PLoS ONE 4 (4), 5068.

Biet, F., Boschiroli, M.L., Thorel, M.F., Guilloteau, L.A., 2005. Zoonotic aspects of Mycobacterium bovis and Mycobacterium avium-intracellulare complex (MAC). Veterinary Research 36 (3), 411-36.

Camels Australia Export - Central Australia - Northern TerritoryAustralia [Internet]. Available from: <http://www.camelsaust. com.au/livebodycond.htm> [Accessed 9 June 2010].

Cleaveland, S., Shaw, D.J., Mfinanga, S.G., Shirima, G., Kazwala, R. R., Eblate, E., Sharp, M., 2007. Mycobacterium bovis in rural Tanzania: Risk factors for infection in human and cattle populations. Tuberculosis 87(1), 30-43.

Cosivi, O., Grange, J.M., Daborn, C.J., Raviglione, M.C., Fujikura, T., Cousins, D., Robinson, R.A., Huchzermeyer, H.F., de Kantor, I., Meslin, F.X., 1998. Zoonotic tuberculosis due to Mycobacterium bovis in developing countries. Emerging Infectious Diseases 4 (1),59-70.

Demelash, B., Inangolet, F., Oloya, J., Asseged, B., Badaso, M., Yilkal, A., Skjerve, E., 2009. Prevalence of Bovine tuberculosis in Ethiopian slaughter cattle based on post-mortem examination. Tropical Animal Health and Production 41(5), 755-765.

Fetene, T., Kebede, N., 2009. Bovine tuberculosis of cattle in three districts of northwestern Ethiopia. Tropical Animal Health and Production 41(2), 273-277.

Godreuil, S., Jeziorski, E., Banuls, A.L., Fraisse, T., Van de Perre, P., Boschiroli, M.L., 2010. Intrafamilial Cluster of Pulmonary Tuberculosis Due to Mycobacterium bovis of the African 1 Clonal Complex. Journal of Clinical Microbiology 48 (12), 4680-4683.

Gumi, B., Schelling, E., Firdessa, R., Aseffa, A., Tschopp, R., Yamuah, L., Young, D. Zinsstag, J., 2011. Prevalence of bovine tuberculosis in pastoral cattle herds in the Oromia region, southern Ethiopia. Tropical Animal Health and Production 43 (6), 1081-1087.

Hiko, A., Agga, G.E., 2011. First-time detection of mycobacterium species from goats in Ethiopia. Tropical Animal Health and Production 43(1), 133-139.

Idigbe, E.O., Anyiwo, C.E., Onwujekwe, D.I., 1986. Human pulmonary infections with bovine and atypical mycobacteria in Lagos, Nigeria. The Journal of Tropical Medicine and Hygiene 89 (3), 143-148.

Inangolet, F.O., Demelash, B., Oloya, J., Opuda-Asibo, J., Skjerve, E., 2008. A cross-sectional study of bovine tuberculosis in the transhumant and agro-pastoral cattle herds in the border areas of Katakwi and Moroto districts, Uganda. Tropical Animal Health and Production 40(7), 501-8.

Javed, M.T., Munir, A., Shahid, M., Severi, G., Irfan, M., Aranaz, A., Cagiola, M., 2010. Percentage of reactor animals to single comparative cervical intradermal tuberculin (SCCIT) in small ruminants in Punjab Pakistan. Acta Tropica 113(1), 88-91.

Jiwa, S., Kazwala, R., Aboud, A., Kalaye, W., 1997. Bovine tuberculosis in the Lake Victoria zone of Tanzania and its possible consequences for human health in the HIV/AIDS era. Veterinary Research Communications 21(8), 533-539.

Kazwala, R., Kambarage, D., Daborn, C., Nyange, J., Jiwa, S., Sharp, J., 2001. Risk Factors Associated with the Occurrence of Bovine Tuberculosis in Cattle in the Southern Highlands of Tanzania. Veterinary Research Communications 25(8), 609-614.

Mamo, G., Kassaye, A., Sanni, M., Ameni, G., 2009. A cross sectional study of camel tuberculosis in Ethiopia. Bulletin of Animal Health and Production in Africa, 57(1).

Mamo, G., Bayleyegn, G., Sisay Tessema, T., Legesse, M., Medhin, G., Bjune, G., Abebe, F., Ameni, G., 2011. Pathology of camel tuberculosis and molecular characterization of its causative agents in pastoral regions of ethiopia. PloS One 6(1), 15862.

Michel, A.L., Müller, B., van Helden, P.D., 2010. Mycobacterium bovis at the animal-human interface: a problem, or not? Veterinary Microbiology 140(3-4), 371-381.

Msangi, B.S.J., Bryant, M., Kavana, P., Msanga, Y., Kizima, J., 1999. Body measurements as a management tool for crossbred dairy cattle at a farm Smallholder condition. In: Proceedings of the meeting in The Tanzanian Society of Animal Production. Tanzania.

Munyeme, M., Muma, J.B., Skjerve, E., Nambota, A.M., Phiri, I.G.K., Samui, K.L., Dorny, P., Tryland, M., 2008. Risk factors associated with bovine tuberculosis in traditional cattle of the livestock/ wildlife interface areas in the Kafue basin of Zambia. Preventive Veterinary Medicine 85(3-4), 317-28.

Munyeme, M., Muma, J., Samui, K., Skjerve, E., Nambota, A., Phiri, I., Rigouts, L. Tryland, M., 2009. Prevalence of bovine tuberculosis and animal level risk factors for indigenous cattle under different grazing strategies in the livestock/wildlife interface areas of Zambia. Tropical Animal Health and Production 41(3), 345352. 
OIE, 2009. Office International des Epizooties Terrestrial manual: Chapter 2.4.7, World Health Organization for Animal Health, Paris.

Oloya, J., Opuda-Asibo, J., Kazwala, R., Demelash, A., Skjerve, E., Lund, A., Johansen, T., Djonne, B., 2008. Mycobacteria causing human cervical lymphadenitis in pastoral communities in the Karamoja region of Uganda. Epidemiology and Infection 136 (5), 636-643.

Oloya, J., Muma, J.B., Opuda-Asibo, J., Djønne, B., Kazwala, R., Skjerve, E., 2007. Risk factors for herd-level bovinetuberculosis seropositivity in transhumant cattle in Uganda. Preventive Veterinary Medicine 80 (4), 318-29.

Oloya, J., Opuda-Asibo, J., Djønne, B., Muma, J., Matope, G., Kazwala, R., Skjerve, E. 2006. Responses to tuberculin among Zebu cattle in the transhumance regions of Karamoja and Nakasongola district of Uganda. Tropical Animal Health and Production 38 (4), 275-283.

Omer, M.K., Skjerve, E., Woldehiwet, Z., Holstad, G., 2001. A crosssectional study of bovine tuberculosis in dairy farms in Asmara, Eritrea. Tropical Animal Health and Production 33(4), 295-303.

Regassa, A., Tassew, A., Amenu, K., Megersa, B., Abunna, F., Mekibib, B., Marcotty, T., Ameni, G., 2010. Erratum to: A cross-sectional study on bovine tuberculosis in Hawassa town and its surroundings, Southern Ethiopia. Tropical Animal Health and Production 42(4), 1039.

Schiller, I., Vordermeier, H.M., Waters, W.R., Whelan, A.O., Coad, M., Gormley, E., Buddle, B.M., Palmer, M., Thacker, T., McNair, J., Welsh, M., Hewinson, R.G. Oesch, B., 2010. Bovine tuberculosis: Effect of the tuberculin skin test on in vitro interferon gamma responses. Veterinary Immunology and Immunopathology 136(12), $1-11$.

Shirima, G.M., Kazwala, R.R.; Kambarage, D.M., 2003. Prevalence of bovine tuberculosis in cattle in different farming systems in the eastern zone of Tanzania. Preventive Veterinary Medicine 57 (3), 167-72.

Shitaye, J., Getahun, B., Alemayehu, T., Skoric, M., Treml, F., Fictum, P., Vrbas, V. Pavlik, I., 2006. A prevalence study of bovine tuberculosis by using abattoir meat inspection and tuberculin skin testing data, histopathological and IS6110 PCR examination of tissues with tuberculous lesions in cattle in Ethiopia. Veterinarni Medicina 51(11), 512-522.

Shitaye, J., Tsegaye, W. Pavlik, I., 2007. Bovine tuberculosis infection in animal and humanpopulations in Ethiopia: a review. Veterinarni Medicina 52 (8), 317-332.

Tschopp, R., Schelling, E., Hattendorf, J., Young, D., Aseffa, A., Zinsstag, J., 2010. Repeated cross-sectional skin testing for bovine tuberculosis in cattle kept in a traditional husbandry system in Ethiopia. The Veterinary Record 167(7), 250-256.

Weinhäupl, I., Schöpf, K.C., Khaschabi, D., Kapaga, A.M., Msami, H. M., 2000. Investigations on the prevalence of bovine tuberculosis and brucellosis in dairy cattle in Dar es Salaam region and in zebu cattle in Lugoba area, Tanzania. Tropical Animal Health and Production 32 (3), 147-54.

Zinsstag, J., Schelling, E., Roth, F., Kazwala, R., 2006. Economics of Bovine Tuberculosis. In: Thoen, C.O., Steele, J.H., Gilsdorf, M.J. (2nd eds), Mycobacterium bovis infection in animals and humans, Blackwell, Boston. 